\title{
AIDS, loss and renewal
}

\section{Opening address to the 20th International AIDS Conference, Melbourne, Australia, 20 July 2014}

\section{Jonathan Mann, loss and grief}

We who gather at this conference in Melbourne are no strangers to cruelty and loss. We know about suffering, irrationality and hatred. We have not been free of these forces for a single day since HIV/AIDS first appeared in our midst 30 years ago.

Every one of us can tell stories about horrible acts and brutal conduct that have added to the misery and danger faced by people living with HIV and by those who love and care for them. We know of people who have died, or are dying, of AIDS; who are seeking love and the human right to respect and to life-saving health care. We know many who are denied justice and human empathy. We are here to affirm that there is another path. We point the way. It is why we have come to Melbourne. It is why we must lift our voices. This is not a time for silence.

In the immediate loss of friends and colleagues who were coming to the conference on MH17, we are reminded, most cruelly, of the earlier death of Jonathan Mann: the first director of the Global Program on AIDS of the World Health Organization. This inspired humanitarian, who did so much to alert the world to the dangers of AIDS, perished with his wife and a plane full of passengers off St John's, Newfoundland, in 1998. He too was on his way to a conference on AIDS. He too had precious gifts to impart. It was a terrible loss to us and to the world. His memory drives us on.

When I was asked to give this opening plenary weeks ago, I little thought that the plane crash that caused those deaths would be multiplied and magnified, this time by deliberate conduct of human beings. That it would kill delegates to our conference and many other peaceful travellers going about their lives, with no harm in their hearts to others. How cruel and selfcentred these murders appear to be. How reckless and outrageous to make such means available to zealots. How much more pain do we have to face in the world of AIDS before we are through this bleak experience?

Be in no doubt that irrational cruelty is, and will remain, our companion on this journey. It requires us to

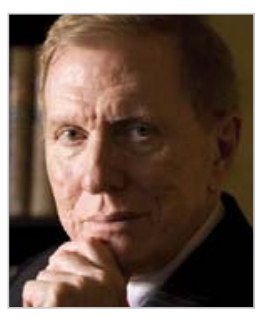

The Hon Michael Kirby

AC, CMG*

Sydney, NSW.

michael@

michaelkirby.com.au

doi: 10.5694/mja14.01040

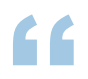

This is not a time for silence

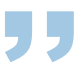

Online first 23/07/14

remember the past president of the International AIDS Society, Joep Lange, and his wife. To think of all the other delegates who expected to be sitting here with us in this hall at this occasion. They devoted themselves to scientific research, to patient care, to law reform and human rights. Would that we could turn the clock back. Would that we could laugh, and think, and dream, and struggle shoulder to shoulder with them here tonight. Yet we cannot.

\section{No strangers to suffering}

So we think of them and of others who have suffered, or are suffering, through irrational, unjust and destructive acts:

- Of Dwayne Jones, murdered in Montego Bay, Jamaica, in July 2013 when she identified as a woman. She was beaten, stabbed, shot and then run over by a car and dumped in a ditch. No one brought to justice. We think of David Kato, a gay activist in Uganda. He too was killed, in January 2011 - hammered to death for opposing the antihomosexual law that has now been brought into effect in his country. We think of Eric Lembembe, a gay activist in Cameroon who was murdered in Yaounde in July 2013. We think of Charles Omondi Racho, who was killed and dumped by the roadside in western Kenya. The violence does not end. Yet brave reformers continue to stand up for their idea of equality and to suffer brutality as a result. Forgive me for speaking of the dead. But their suffering, in our context, is a demand for action.

- We think of the mothers and families in South Africa who, inspired by global efforts, challenged the denial to them of antiretrovirals which, for a mere dollar, would save their babies from HIV infection.

- We think of sex workers, drug users, prisoners, transsexuals, the disabled people living with HIV. For them our conference theme of "Nobody left behind" must often seem a cruel irony.

- We think of the bitter disappointments of legislatures that have failed to act. And of courts that have shown no insight. Like the recent decision in India that reversed the noble judgment of the Delhi High Court in the Naz Foundation case invalidating the colonial law on gays.

* Michael Kirby is a member of the inaugural World Health Organization Global Commission on AIDS (1988-92); Commissioner of the United Nations Development Programme Global Commission on HIV and the Law (201112); member of the UNAIDS Reference Group on HIV and Human Rights (2001-); Commissioner of the UNAIDS and Lancet Commission: From AIDS to Sustainable Health (2013-); former Justice of the High Court of Australia (1996-2009); member of the Pacific Friends of the Global Fund; and Patron of the Kirby Institute, University of New South Wales, Sydney, Australia.

- We think of horrible new laws spreading throughout Africa and the violence that they breed. That violence sets back the struggle against AIDS. 
- And we think of the lonely patients dying without hope. And the injecting drug users and other outcasts, rejected by family and society, where therapy would restore their lives and sense of self-worth.

These thoughts too propel us on.

All of us in Melbourne, and many far away, know that those of our companions who were lost on their way to join us also knew these things. They too had these images in their minds, as they set out to this continental and welcoming country. They would expect us to pick up our shattered spirits. They would demand that we renew and redouble our efforts. They would see those efforts as small but vital pieces of the great human puzzle that seeks to build a world that respects human rights, and heralds the day when the suffering of AIDS will be over.

\section{Apologies and affirmations}

I owe many apologies for presuming to speak at this moment of grief and pain:

- Apologies because the voice should really belong to those who knew and could tell us the simple stories of our friends who have been lost. And of the individual and collective contributions that they have made to the struggle in which we are still engaged.

- Apologies because I am not a person who is living with HIV or AIDS. Jonathan Mann always insisted on the importance of listening to the voices of those who are infected and understanding what they say. Who will ever forget the electric words of Justice Edwin Cameron, at the Durban Conference, as he castigated the government of his country for the crazy, wrong refusal (now reversed) to acknowledge the true science of HIV.

- Apologies because I am not a disabled person facing HIV. I know now that it had been hoped, and urged, that a voice would be given on this occasion to such a speaker so that truly no one would be left behind. I hope that such voices will be raised in these days in Melbourne, loud and clear.

Yet I can speak as one who has tasted the bitter dregs of discrimination and hatred, because of my sexuality. By reason of that ethos, I lost 12 greatly loved friends in the early days of the epidemic. They too suffered discrimination, hostility, indifference, disgust. But they overcame these emotions. They lived and then they died in the sure conviction that things would get better. And so, through science, and education, and knowledge and human kindness, this has happened. It has occurred in Australia and in other lands. Step by step it has happened. Yet the enlightenment has still to reach many places where all too many get left behind.

\section{Six vital lessons}

In 1988, I spoke not at the opening but at the closing session of the Stockholm AIDS Conference. Re-reading my remarks has taught the essential simplicities of the key messages that must guide us still, here in Melbourne. They were true then. They are still true today. We must rediscover their clarity and direction. By repeating the basic lessons, we may gain success in persuading the sceptical. We may influence change in the directions essential if no one is to be left behind.

First, there is the vital importance of science. All laws and strategies to deal with HIV and AIDS must be based on science, not mythology and prejudice. Science has brought us the miracle of triple combination therapy and new lines of treatment. Science has relieved suffering. It has made a big difference. And nearly 15 million people with HIV are now the beneficiaries.

Second, we must listen to the voices. As Jonathan Mann taught us, people living with HIV and AIDS must be at the very forefront of our efforts. They will bring us realism. They will demand action.

Third, we must help political leaders to understand the AIDS paradox, taught by Jonathan Mann. Paradoxically, and almost counterintuitively, the best way in current circumstances to get people to testing and to reduce the toll of death and suffering is not by punishing and isolating those infected with HIV. It is actually by protecting them. By entering their minds. By getting them to seek help. Law and policy must be made part of the solution, not part of the problem, of AIDS.

Fourth, the HIV paradox can be explained and accepted by politicians, including on both sides of the political divide. No side in politics has a monopoly on wisdom or compassion on AIDS. Many have contributions to make. We saw this in Australia in the early frantic days, 30 years ago. Dr Neal Blewett, Labor federal health minister, and his Coalition counterpart, Dr Peter Baume, came together to embrace the AIDS paradox. They reached out in protection of gay men, sex workers, injecting drug users and others. In Australia, throughout the Hawke, Keating, Howard, Rudd, Gillard and Abbott governments, we have retained this steady course. It is something we can be proud of. It is a strategy with occasional imperfections and failings. But we can put it before the world as a basic model for effective AIDS policies.

Fifth, we have resisted many traditional approaches to epidemics. From the earliest days, it was clear that quarantine, law's conventional response, would not work. The early promises of a medical "silver bullet" a cure or a vaccine - did not eventuate. They continue to elude us. Yet the antiretrovirals and then the dramatic outreach to provide therapy as prevention to 15 million people made human rights a reality. Perhaps after all, no one would be left behind.

Sixth, in many countries, leaders have tragically failed to embrace the paradoxes of AIDS. They have talked about action. They have received the subventions for antiretroviral drugs. But they have failed dismally to defend the human rights and lives of their own citizens. It is beyond time for the adoption by these leaders of initiatives that work. Without such reforms and also without changing the global laws on intellectual 
property, people will die needlessly. It is as simple as that. Someone must tell those who will not act the practical facts of life in our world. They cannot expect taxpayers in other countries to shell out, indefinitely, huge funds for antiretroviral drugs if they simply refuse to reform their own laws and policies to help their own citizens. Mickey Mouse in Fantasia in 1940 portrayed the global state we are now in. Too many countries are leaving the tap running full pelt. To sweep up the flood with a solitary broom is not going to work. We must turn off the taps. And that will not happen without an embrace of the kind of laws and policies we have long adopted in Australia.

\section{Sustaining the Australian model}

Do not think for a moment that it was easy for us to do as we have done in this country. It was hard. But it has held firm over 20 years.

So how have we maintained our model on the AIDS response for so long? AIDS activists have done so by working closely and respectfully with political leaders of every persuasion. By appealing to human empathy, to human rights and to the cold realities of economics and the costs of leaving the taps running.

Australia's Prime Minister, Tony Abbott, and his government, have engaged with AIDS activists. They have worked with them in search of common ground. This dialogue surely has lessons for other countries. We can learn from them. But I believe they can learn from us:

- Reversing the predecessor government's decision, the Abbott government in Australia has restored Australia's practical commitment to the Global Fund. It has promised \$200 million in the place of a zero subvention that reversed past commitments.

- Our Foreign Minister, Julie Bishop MP, has been a stalwart defender of Australia's regional overseas aid model. The government knows that viruses can enter this country far more easily than boats. They realise that it is in our interests, as much as those of others, to help our neighbours to reverse the pandemic in their own lands. Julie Bishop has also insisted, as Jonathan Mann did at the outset, that AIDS is a major women's health issue.

- As a conviction politician and an unabashed conservative, Tony Abbott may be able to help us in this world to reach out to those political leaders, at the coming G20 Summit in Brisbane and in the meetings of the Commonwealth of Nations, to break the deadly logjam of inaction or wrong actions. Many of those who have left the taps of infection still open are more likely to listen to him than to others that talk a language that they abhor. Conservatives can be vital allies in the struggle against AIDS. We should never forget that it was President George W Bush in the United States who established the PEPFAR fund and promoted the Global Fund that has helped save millions of vulnerable lives.

\section{Renewing our commitment}

And so, once again, we remember Jonathan Mann and meet together in this struggle. We come to renew our commitment to ourselves, to our lost friends, and to the strategies that work. Rich and poor. Men and women. People living with HIV and those who love and support them. Religious and non-religious. Straight and gay. Liberals and conservatives. We are in this together.

To those who live with HIV, to those who have died of AIDS and to those who have died in the struggle to advance the principles of the Melbourne Declaration, this conference should give a renewed commitment: to continue down the paradoxical path that has been shown to work. Never to allow the forces of cruelty and ignorance to deflect us. And never to be content while anyone is at risk of being left behind. 